Volume 1 Nomor 2 Edisi Desember 2013
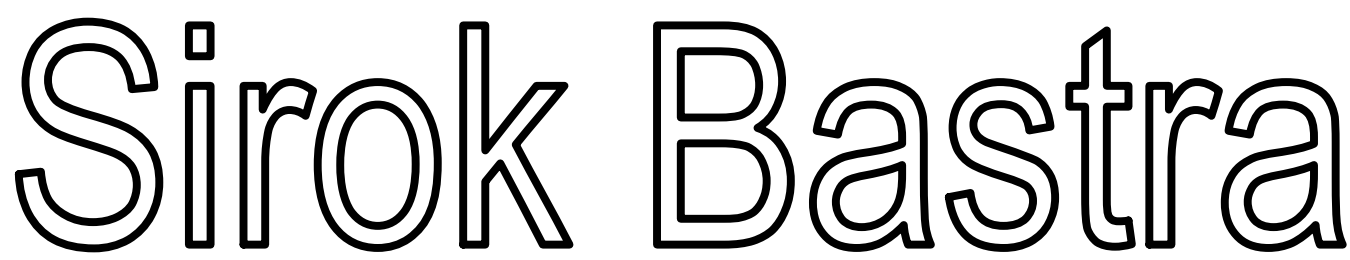

J URNAL ILMIAH KEBAHASAAN DAN KESASTRAAN

\begin{tabular}{|c|c|c|c|c|c|}
\hline $\begin{array}{c}\text { Sirok Bastra } \\
\text { Jurnal Kebahasaan dan } \\
\text { Kesastraan }\end{array}$ & Volume 1 & Nomor 2 & $\begin{array}{c}\text { Hlm. } \\
123-249\end{array}$ & $\begin{array}{c}\text { Pangkalpinang, } \\
\text { Desember } \\
2013\end{array}$ & $\begin{array}{c}\text { ISSN } \\
2354-7200\end{array}$ \\
\hline
\end{tabular}

KANTOR BAHASA KEPULAUAN BANGKA BELITUNG 

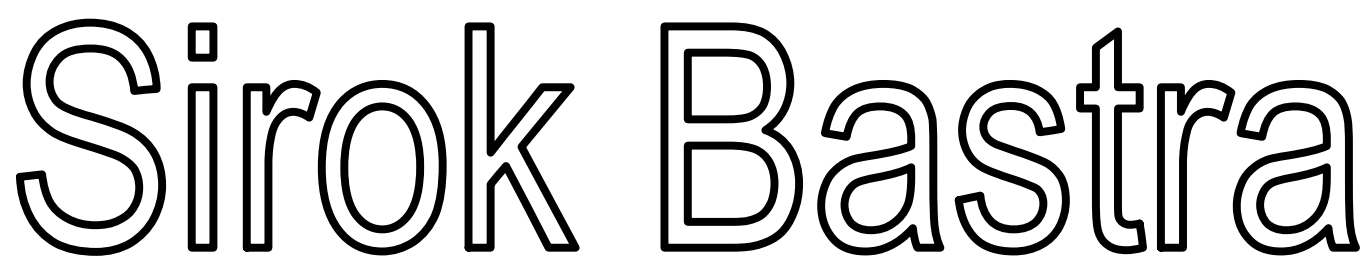

\section{J URNAL ILMIAH KEBAHASAAN DAN KESASTRAAN}

Jurnal ini merupakan wadah informasi mengenai kebahasan, kesastraan, dan pengajarannya yang memuat hasil penelitian, studi kepustakaan, dan tulisan ilmiah bidang kebahasan, kesastraan, dan pengajarannya. Jurnal ini terbit dua kali setahun, yakni Juni dan Desember, serta terbit sejak Juni 2013.

\section{Penanggung Jawab}

Kepala Kantor Bahasa Provinsi Bangka Belitung

Drs. Umar Solikhan, M.Hum.

\section{Mitra Bestari}

Prof. Dr. Agus Nuryatin, M.Hum. (Bidang Bahasa dan Pengajarannya)

Prof. Amrin Saragih, Ph.D., M.A. (Bidang Sastra dan Pengajarannya)

Dr. Felicia Nuradi Utorodewo, M.Hum. (Bidang Bahasa dan Pengajarannya)

Dr. Pujiharto, M.Hum. (Bidang Sastra dan Pengajarannya)

\section{Pemimpin Redaksi}

Rahmat Muhidin, S.S.

\section{Penyunting}

Prima Hariyanto, S.Hum.

\section{Perancang Sampul}

Feri Pristiawan, S.S.

\section{Kesekretariatan}

Khaliffitriansyah, S.Pd. Dea Letriana Cesaria, S.Hum.

Lia Aprilina, S.Pd.

Andrian Priyatno, A.Md.

Elzam

\section{Alamat Redaksi dan Penerbit}

Kantor Bahasa Provinsi Bangka Belitung

Ruko Permata 7, Jalan Solihin G.P. Km 4, Pangkalpinang, Kep. Bangka Belitung

Telp./Faks.: 0717-438455, Pos-el: sirokbastra@gmail.com

Pemuatan suatu tulisan dalam jurnal ini tidak berarti redaksi menyetujui isi tulisan tersebut. Isi tulisan menjadi tanggung jawab penulis. Tulisan telah ditinjau oleh mitra bestari. Setiap karangan dalam jurnal ini dapat diperbanyak setelah mendapat izin tertulis dari penulis, redaksi, dan penerbit. 


\section{KATA PENGANTAR}

Puji syukur ke hadirat Pemilik dan Pencipta semesta ini yang memiliki kuasa atas diri-Nya sendiri. Dialah Tuhan Yang Maha Esa yang telah memberikan rahmat dan hidayah-Nya sehingga Volume 1 Nomor 2 Jurnal Sirok Bastra dapat terbit tepat pada waktunya.

Pada nomor kedua ini, dimuat sebelas tulisan, yakni enam tulisan kebahasaan, empat kesastraan, dan satu pengajaran sastra. Dari segi bahasa, sebagian besar tulisan disajikan dalam bahasa Indonesia, hanya dua tulisan yang disajikan dalam bahasa Inggris. Kami mengucapkan terima kasih kepada para penulis yang telah bersedia menerbitkan karya mereka pada edisi ini. Para penulis merupakan para peneliti, pakar, dosen, dan mahasiswa dari berbagai perguruan tinggi dan instansi. Terima kasih juga kami sampaikan kepada para mitra bestari kami yang telah memberi ulasan terhadap tulisan-tulisan yang masuk ke redaksi.

Demi memenuhi keberagaman isi dan penulis, Sirok Bastra membuka kesempatan bagi para peneliti dan penulis menyampaikan hasil penelitian dan pemikiran mutakhir dalam bidang kebahasaan, kesastraan, dan pengajarannya.

Pangkalpinang, Desember 2013

Tim Redaksi 


\section{UCAPAN TERIMA KASIH UNTUK MITRA BESTARI}

Redaksi Sirok Bastra mengucapkan terima kasih kepada para mitra bestari yang telah meninjau, menimbang, dan mengulas makalah-makalah yang diterbitkan dalam Sirok Bastra Volume 1 Nomor 2, edisi Desember 2013, yakni

Prof. Dr. Agus Nuryatin, M.Hum.

Bidang Sastra dan Pengajarannya

Universitas Negeri Semarang

Semarang, Jawa Tengah

Prof. Amrin Saragih, Ph.D., M.A.

Bidang Bahasa dan Pengajarannya

Universitas Negeri Medan

Medan, Sumatra Utara

Dr. Felicia Nuradi Utorodewo, M.Hum.

Bidang Bahasa dan Pengajarannya

Universitas Indonesia

Depok, Jawa Barat

\section{Dr. Pujiharto, M.Hum.}

Bidang Sastra dan Pengajarannya

Universitas Gadjah Mada

Yogyakarta, Daerah Istimewa Yogyakarta 


\section{DAFTAR ISI}

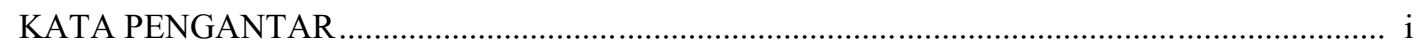

UCAPAN TERIMA KASIH UNTUK MITRA BESTARI .................................................... ii

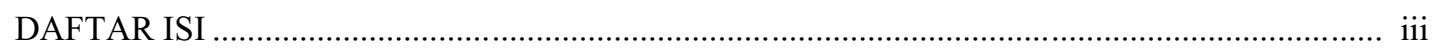

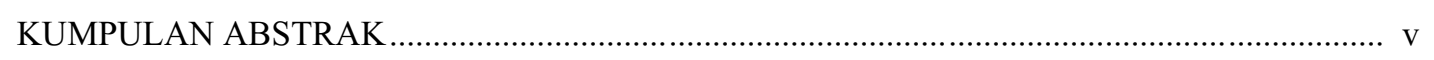

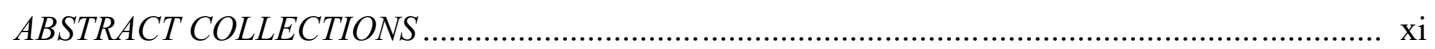

BAHASA INDONESIA DALAM INFORMASI DAN IKLAN DI RUANG PUBLIK KOTA PANGKALPINANG

(Indonesian in Information and Advertising in Public Space Pangkalpinang)

Umar Solikhan $123-129$

PERBEDAAN MAKNA NOMINA BERAFIKS $P E-, P E R-, P E--A N$, DAN $P E R--A N$ DALAM NASKAH HIKAYAT BAYAN BUDIMAN, HIKAYAT MUHAMMAD HANAFIYYAH, DAN HIKAYAT RAJA PASAI

(Affixed Noun Meaning Differences of pe-, per-, pe--an, and per--an in The Hikayat Bayan Budiman, Hikayat Muhammad Hanafiyyah, and Hikayat Raja Pasai Manuscripts)

Rindias H. Fatmasari $131-147$

WACANA RUBRIK INTIMATE DI MAJALAH DIGITAL INTERAKTIF MALE

(Intimate Rubric in Male Digital Interactive Magazine Discourse)

Prima Hariyanto $149-160$

AN ACOUSTICAL CONTRASTIVE ANALYSIS OF SUNDANESE CENTRAL VOWELS (Analisis Konstrastif Akustik Vokal Pusat Bahasa Sunda)

Yusup Irawan. $161-175$

KATA SUDAH SEBAGAI PENANDA ASPEK DENGAN AWALAN TER-

The Word of Sudah as An Aspect with Prefix Ter-

Dea Letriana Cesaria $177-182$

PERUBAHAN DAN PERGESERAN MAKNA DALAM KATA-KATA BERDERIVASI NOMINA KE VERBA YANG MENGANDUNG AFIKS $M E(N)-, M E(N)-K A N$, DAN $M E(N)-I$ PADA SURAT KABAR HARIAN KOMPAS

(Change and Shift of Meaning in The Derivated Words Nomine to Verb That Contain Affixes $m e(N)-$, me(N)-kan, dan me(N)- $i$ in The Kompas The Daily Newspaper)

Teodora Nirmala Fau $183-193$

MENCIPTA-KREATIF NASKAH DRAMA DENGAN STRATEGI MENULIS TERBIMBING (Creative Writing of Playscript eith Guided Writing Strategy)

Sony Sukmawan. $195-205$ 
PENGARUH KONSEP HAGABEON, HAMORAON, DAN HASANGAPON TERHADAP

KETIDAKSETARAAN GENDER DALAM AMANG PARSINUAN

(The Influence of Hagabeon, Hamoraon, and Hasangapon Concept for Gender Inequality in Amang Parsinuan)

Fransiska Simangunsong $207-220$

PERSPEKTIF PENGARANG MENGENAI RELASI ANTARA MANUSIA DAN

LINGKUNGAN HIDUP DALAM NOVEL PARTIKEL KARYA DEWI LESTARI: SEBUAH KAJIAN EKOKRITISISME

(Author's Perspective on The Relationship Between Humans and The Environment in The Novel Partikel Written by Dewi Lestari: an Ecocriticism Studies)

Alfi Yusrina Ramadhani $221-229$

FENOMENA HUKUM ADAT BALI TERHADAP BAYI KEMBAR BUNCING DALAM

NOVEL INCEST KARYA I WAYAN ARTIKA

Bali Custom Law Phenomenon of Kembar Buncing Infant in I Wayan Artika Novel Incest Annisa Aprinandri Irwin dan Khansa Khairunnisa $231-241$

RELIGIOUS AND MORAL VALUES IN MADURA FOLKTALES

Religiositas dan Nilai Moral dalam Cerita-Cerita Rakyat Madura

Imron Wakhid Harits. $243-249$ 


\title{
BAHASA INDONESIA DALAM INFORMASI DAN IKLAN DI RUANG PUBLIK KOTA PANGKALPINANG
}

\author{
Indonesian in Information and Advertising in Public Space Pangkalpinang \\ Umar Solikhan \\ Kantor Bahasa Provinsi Bangka Belitung \\ Ruko Permata No. 7, Jalan Solikhin G.P. Km 4, Pangkalpinang \\ pos-el: kumarsanders@yahoo.co.id
}

(diterima 4 September 2013, disetujui 30 September 2013, revisi terakhir 27 November 2013)

\begin{abstract}
Abstrak
Pemakaian bahasa Indonesia, khususnya dalam informasi dan iklan, di tempat umum di wilayah Pangkalpinang belum menggambarkan pemakaian bahasa Indonesia yang baik dan benar. Kesalahan pemakaian paling banyak terjadi pada bidang ejaan, disusul kesalahan-kesalahan lain seperti pada bentuk dan pilihan kata, kalimat, dan penggunaan bahasa asing dan bahasa daerah yang tidak mengikuti aturan. Penyebab kesalahan itu sendiri adalah sikap terhadap bahasa Indonesia masih belum memenuhi harapan. Padahal, sebagai bangsa yang berbudaya dan menjunjung persatuan bangsa Indonesia, sikap positif terhadap bahasa Indonesia senantiasa harus dijaga.
\end{abstract}

Kata kunci: informasi, ruang publik, kesalahan berbahasa, sikap

\begin{abstract}
Indonesian usage, particularly in the information and advertising, in public places in the region Pangkalpinang have not described the good and correct use of Indonesian yet. Usage errors occur most commonly in the areas of spelling, followed by other errors such as the shape and choice of words, sentences, and the use of foreign languages and regional languages that do not follow the rules. The cause of the error itself is the attitude of the Indonesian still has not met expectations. In fact, as a civilized nation and uphold the national unity of Indonesia, a positive attitude towards Indonesian should always be maintained.
\end{abstract}

Keywords: information, public space, speaking mistakes, attitudes

\section{PENDAHULUAN}

\subsection{Latar Belakang}

Masyarakat Provinsi Kepulauan Bangka Belitung yang dikenal bilingual (mayoritas suku Melayu Bangka) atau bahkan trilingual (sebagian besar etnis Tionghoa) pada umumnya menggunakan bahasa daerah (bahasa Melayu Bangka dan/bahasa Cina) dan bahasa Indonesia dalam aktivitas kehidupan seharihari. Pemilihan penggunaan satu di antara dua/tiga bahasa tersebut tentunya disesuaikan dengan konteks situasi yang melatarbelakangi penyampaian informasi sehingga pemilihan bahasa yang tepat dalam situasi yang tepat akan melahirkan penggunaan bahasa yang tepat. Akan tetapi, berdasarkan pengamatan, penggunaan bahasa Indonesia oleh masyarakat Provinsi Bangka Belitung di tempat umum (ruang publik), khususnya di Kota Pangkalpinang, belum seperti yang diharapkan. Hal itu disebabkan masih banyaknya kesalahan penulisan dan sering juga tercampuraduknya penggunaan bahasa Indonesia dengan bahasa daerah pada situasi yang semestinya mempergunakan bahasa Indonesia yang baik dan benar. Keadaan itu diperparah oleh maraknya penggunaan bahasa asing yang juga dicampuradukkan dengan bahasa Indonesia. Kondisi seperti itu tentunya dirasa membawa kekhawatiran tersendiri terhadap keberadaan bahasa Indonesia.

\subsection{Tujuan Penelitian}

Penelitian ini mencoba melihat penggunaan bahasa di tempat-tempat umum, khususnya dalam informasi dan iklan di Kota Pangkalpinang. Pemakaian bahasa yang dimaksud adalah segala bentuk tuturan tertulis, baik yang terdapat pada papan nama, papan pengumuman, spanduk, baliho, dan lainlain yang tujuannya untuk memberi pesan berupa informasi dan iklan kepada masyarakat luas. 
Tujuan penelitian adalah untuk mendapatkan gambaran yang sesungguhnya mengenai penggunaan bahasa Indonesia masyarakat Kota Pangkalpinang, khususnya dalam informasi dan iklan, di tempat umum.

\subsection{Metode Penelitian}

Kegiatan penelitian atau pemantauan penggunaan bahasa di tempat umum ini dilaksanakan di Kota Pangkalpinang, Provinsi Bangka Belitung. Dipilihnya Kota Pangkalpinang sebagai daerah pengamatan (DP) ini karena sebagai ibukota Provinsi Kepulauan Bangka Belitung, Pangkalpinang merupakan pusat segala aktivitas dalam bidang pemerintahan, perdagangan, kemasyarakatan, dan lain-lain, khususnya menyangkut sendi-sendi kehidupan modern sehingga dapat dikatakan Pangkalpinang merupakan cerminan kehidupan masyarakat Provinsi Kepulauan Bangka Belitung.

Pengumpulan data menggunakan metode simak. Metode simak adalah metode yang digunakan untuk memperoleh data dengan menyimak penggunaan bahasa, baik lisan maupun tertulis (Mahsun, 2005:90). Secara khusus metode penyimakan dalam hal ini menggunakan teknik perekaman tulisan-tulisan dengan pemotretan. Hasil pemotretan berupa foto-foto yang berwujud gambar dan tulisan kemudian dianalisis secara deskriptif dengan menggunakan kaidah-kaidah yang ada dalam bahasa Indonesia, seperti Pedoman Umum EYD (Pusat Bahasa, 2004), Tata Bahasa Baku Bahasa Indonesia (Alwi, Hasan dkk., 2003), Buku Praktis Berbahasa Indonesia 1 dan 2 (Sugono, Dendy dkk., 2008), dan lain-lain, serta teori mengenai kesalahan berbahasa.

\section{KERANGKA TEORETIS}

Makna iklan sendiri menurut KBBI (2008:521) adalah berita pesanan untuk mendorong, membujuk khalayak ramai agar tertarik pada barang dan jasa yang ditawarkan atau pemberitahuan kepada khalayak mengenai barang dan jasa yang dijual, dipasang di media massa atau di tempat umum. Shurter (1971:243) menyatakan struktur iklan disusun untuk (1) merangsang minat pembaca, (2) menimbulkan hasrat akan hasil produksi, (3) meyakinkan bahwa hasil produksi atau pelayanan itu adalah yang terbaik, dan (4) mendorong pembaca untuk bertindak. Adapun ruang publik yang dimaksud adalah tempat-tempat yang peruntukannya untuk masyarakat umum, seperti jalan raya, terminal, stasiun, taman kota, tempat rekreasi, dan kantor-kantor pemerintah.

Undang-Undang Republik Indonesia Nomor 24 Tahun 2009 tentang Bendera, Bahasa, dan Lambang Negera, serta Lagu Kebangsaan (Badan Pengembangan dan Pembinaan Bahasa, 2011:15-16) secara garis besar menjelaskan bahwa nama-nama bangunan dan lain-lain dan semua informasi yang sifatnya pelayanan umum wajib memakai bahasa Indonesia.

Permasalahan ketidaktepatan penggunaan bahasa Indonesia di ruang publik sendiri disebabkan oleh banyak faktor. Kesalahan tersebut dapat disebabkan mulai karena kurangnya sikap positif penutur terhadap bahasa Indonesia sampai karena ketidaktahuan mereka terhadap kaidah-kaidah pemakaian bahasa Indonesia.

Sikap seorang penutur terhadap suatu bahasa dapat mempengaruhi performance-nya dalam menggunakan bahasa tersebut. Anderson (1974) via Suhardi (1996:35) menyatakan, sikap bahasa merupakan tata keyakinan yang berhubungan dengan bahasa yang berlangsung relatif lama, tentang suatu objek bahasa yang memberikan kecenderungan kepada seseorang untuk bertindak dengan cara tertentu yang disukainya. Sikap bahasa terhadap suatu bahasa dapat pula dilihat dari bagaimana keyakinan penutur terhadap suatu bahasa; bagaimana perasaan penutur terhadap bahasa itu; bagaimana kecenderungan bertindak tutur (speech act) terhadap suatu bahasa. Halim (1978:3) berdasarkan pendapat Oppenheim (1976:106-107) merumuskan bahwa dalam kaitan dengan sikap terhadap bahasa, apabila seseorang cenderung memakai bahasa Indonesia, itu berarti bahwa ia memperlihatkan sikap yang positif terhadap bahasa Indonesia.

\section{HASIL DAN PEMBAHASAN}

\subsection{Kesalahan-Kesalahan Penggunaan Bahasa Indonesia di Ruang Publik Kota Pangkalpinang}

Dari hasil pemantauan di lapangan terhadap tulisan-tulisan yang ada di media-media yang menjadi sasaran pemantauan, seperti papan pengumuman, spanduk, dan baliho yang dipasang di tempat-tempat 
umum (ruang publik), didapatkan gambaran secara umum bahwa penggunaan bahasa Indonesia masyarakat Pangkalpinang di tempat umum masih belum seperti yang diharapkan. Memang dilihat dari sudut ilmu komunikasi, tujuan komunikator untuk memberikan pesan atau informasi kepada masyarakat luas melalui bahasa tulis secara umum sudah menggunakan bahasa yang ringkas dan padat sehingga tidak berkesan bertele-tele.

Dilihat dari segi pemakaian bahasa Indonesia yang baik, secara umum tulisan-tulisan yang ada juga sudah cukup baik meskipun masih terdapat beberapa kesalahan. Pada umumnya komunikator dalam menyampaikan informasi sudah memperhatikan situasi pemakaian bahasa sehingga apa yang ditulis sesuai dengan konteksnya, seperti dalam situasi formal menggunakan bahasa yang formal. Namun, dari sudut kebenaran pemakaian bahasa Indonesia, tulisan-tulisan yang dibuat masih terdapat kesalahankesalahan.

Berikut ini contoh-contoh permasalahan penulisan di tempat umum yang dibuat oleh berbagai kalangan, baik dari segi ejaan, bentuk dan pilihan kata, maupun kalimat.

\subsubsection{Ejaan}

Dari segi penulisan ejaan, secara umum masih cukup banyak terdapat kesalahan, di antaranya seperti berikut ini.

\section{Penggunaan Tanda Baca \\ - Tanda Titik}

Tabel di bawah memperlihatkan penggunaan tanda titik untuk singkatan $P T$ (perseroan terbatas) dan $C V$ yang ditulis PT. dan CV. Padahal, ketentuannya singkatan nama resmi lembaga, badan, atau organisasi yang terdiri atas huruf awal kata yang mengggunakan huruf kapital, tidak diikuti oleh tanda titik. Contoh lain untuk penggunaan tanda titik yang salah antara lain pada singkatan seperti Brig.jend (brigadir jenderal), TH. (tahun), dan R.S. (rumah sakit).

\begin{tabular}{|l|l|l|}
\hline NO & \multicolumn{1}{|c|}{ SALAH } & \multicolumn{1}{c|}{ BENAR } \\
\hline 1. & PT. & PT \\
\hline 2. & PD. & PD \\
\hline 3. & CV. & CV \\
\hline 4. & Brig. Jend. & Brigjen \\
\hline 5. & TH. & THN. atau Thn. atau Tahun \\
\hline 6. & RS. & RS \\
\hline
\end{tabular}

\section{- Tanda Koma}

Kesalahan ejaan pada penggunaan tanda koma umumnya terjadi pada bentuk-bentuk yang menggunakan perincian, seperti Dinas Ketenteraman, Ketertiban dan Perlindungan Masyarakat. Pada bentuk seperti itu seharusnya ada tanda koma sebelum kata dan. Di samping itu, tanda koma juga seharusnya dipakai untuk memisahkan bagian-bagian alamat. Contoh:

\begin{tabular}{|l|l|l|}
\hline NO. & \multicolumn{1}{|c|}{ SALAH } & \multicolumn{1}{|c|}{ BENAR } \\
\hline 1. & $\begin{array}{l}\text { Dinas Ketentraman, Ketertiban dan } \\
\text { Perlindungan Masyarakat. }\end{array}$ & $\begin{array}{l}\text { Dinas Ketenteraman, Ketertiban, dan Perlindungan } \\
\text { Masyarakat }\end{array}$ \\
\hline 2. & $\begin{array}{l}\text { Praktek Pengobatan Sin She hari } \\
\text { Selasa,Kamis,Jumat\&Minggu. }\end{array}$ & $\begin{array}{l}\text { Praktik Pengobatan Sin She hari Selasa, Kamis, } \\
\text { Jumat, dan Minggu. }\end{array}$ \\
\hline 3. & $\begin{array}{l}\text { Untuk rencana sekolah, umroh/haji, qurban, } \\
\text { pensiun dan rencana apapun, paling cocok } \\
\text { pakai Tabungan BERENCANA BSM. }\end{array}$ & $\begin{array}{l}\text { Untuk rencana sekolah, umroh/haji, kurban, pensiun, } \\
\text { dan rencana apapun, paling cocok pakai Tabungan } \\
\text { BERENCANA BSM. }\end{array}$ \\
\hline 4. & $\begin{array}{l}\text { Jl. Jendral Sudirman No.30 Pangkalpinang } \\
\text { Bangka }\end{array}$ & $\begin{array}{l}\text { Jln. Jenderal Sudirman No. 30, Pangkalpinang, } \\
\text { Bangka }\end{array}$ \\
\hline 5. & $\begin{array}{l}\text { ADIPURA MERUPAKAN CERMIN SIKAP } \\
\text { DAN PERILAKU MASYARAKAT } \\
\text { PANGKALPINANG YANG BERSIH, AMAN, } \\
\text { RAPI, TERTIB DAN INDAH }\end{array}$ & $\begin{array}{l}\text { PERILAKU MASG BERSIH, AMAN, RAPI, TERTIB, DAN } \\
\text { YANAKAKAN CERMIN SIKAP DAN }\end{array}$ \\
\hline
\end{tabular}




\section{- Huruf Kapital}

Kesalahan penggunaan huruf kapital umumnya karena tidak mematuhi aturan yang ada di dalam buku pedoman EYD. Selain itu adapula karena ketidakkonsistenan penggunaan huruf kapital pada kalimat, yaitu ada kata yang ditulis dengan huruf kapital dan ada yang tidak. Contoh:

\begin{tabular}{|c|c|c|}
\hline NO. & SALAH & BENAR \\
\hline 1. & $\begin{array}{l}\text { KREDIT di COLUMBUS Bayar Angsuran Bisa } \\
\text { di Kantor PO E-Mobile POS di Seluruh } \\
\text { Indonesia }\end{array}$ & $\begin{array}{l}\text { Kredit di Columbus, bayar angsuran bisa di Kantor } \\
\text { POS/E-Mobile Post } \\
\text { di seluruh Indonesia }\end{array}$ \\
\hline 2. & $\begin{array}{l}\text { Untuk rencana sekolah, umroh/haji, qurban, } \\
\text { pensiun dan rencana apapun, paling cocok } \\
\text { pakai Tabungan BERENCANA BSM. }\end{array}$ & $\begin{array}{l}\text { Untuk rencana sekolah, umroh/haji, kurban, pensiun, } \\
\text { dan rencana apapun, paling cocok pakai Tabungan } \\
\text { Berencana BSM. }\end{array}$ \\
\hline 3. & $\begin{array}{ccc}\text { CEGAH } & \text { ANAK } & \text { ANDA } \\
\text { PENYALAHGUNAAN "NARKOBA". }\end{array}$ & $\begin{array}{lccc}\text { CEGAH } & \text { ANAK } & \text { ANDA } & \text { DARI } \\
\text { PENYALAHGUNAAN "NARKOBA" atau } & \\
\text { Cegah Anak Anda dari Penyalahgunaan "Narkoba". }\end{array}$ \\
\hline 4. & 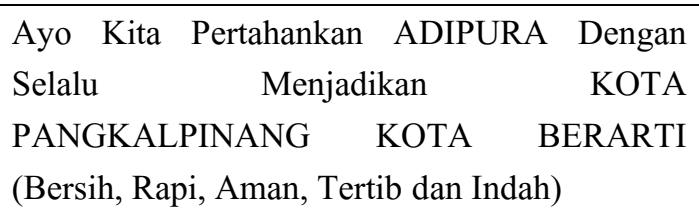 & $\begin{array}{l}\text { Ayo kita pertahankan Adipura dengan selalu } \\
\text { menjadikan Pangkalpinang sebagai kota yang } \\
\text { Berarti (bersih, rapi, aman, tertib dan indah). }\end{array}$ \\
\hline 5. & e-KTP Mencegah KTP Ganda Dan Palsu & E-KTP mencegah KTP ganda dan palsu. \\
\hline
\end{tabular}

\section{- Penulisan Kata}

Kesalahan penulisan kata yang sering terjadi adalah pada penulisan kata depan dan gabungan kata. Kata depan sering dirancukan dengan awalan sehingga penulisannya digabung dengan kata yang mengikutinya, sedangkan untuk gabungan kata, katakata yang seharusnya digabung penulisannya tidak digabung dan sebaliknya kata-kata yang seharusnya tidak digabung penulisannya digabung. Contoh:

\begin{tabular}{|l|l|l|}
\hline NO. & \multicolumn{1}{|c|}{ SALAH } & \multicolumn{1}{c|}{ BENAR } \\
\hline 1. & diseluruh & di seluruh \\
\hline 2. & DIKAWASAN & DI KAWASAN \\
\hline 3. & Disini & Di sini \\
\hline 4. & Lalu lintas & Lalulintas \\
\hline 5. & Non formal & Nonformal \\
\hline 6. & DIUSIA & DI USIA \\
\hline 7. & ketempat & ke tempat \\
\hline 8. & Sub Dinas & Subdinas \\
\hline 9. & sub unit & Subunit \\
\hline
\end{tabular}

\subsubsection{Bentuk dan Pilihan Kata}

Permasalahan dalam hal ini biasanya berupa ketidakbenaran dalam menuliskan bentuk kata, seperti kesalahan dalam menuliskan kata dari serapan bahasa asing. Selain itu pada masyarakat Bangka, khususnya di Pangkalpinang, terdapat bentuk-bentuk kata yang unik yang meskipun penulisannya kurang tepat, tetapi pemakaiannya sudah memasyarakat, seperti: ada jual, tersedia, dan dikontrak yang banyak terdapat di depan warung atau toko dan rumah-rumah yang akan dikontrakkan. Contoh:

\begin{tabular}{|l|l|l|}
\hline NO. & \multicolumn{1}{|c|}{ SALAH } & \multicolumn{1}{c|}{ BENAR } \\
\hline 1 & Komplek & Kompleks \\
\hline 2. & Telpon/phone & Telepon \\
\hline 3. & Jendral & Jenderal \\
\hline 4. & Standart & Standar \\
\hline 5. & Ada jual bensin & Jual bensin \\
\hline 6. & Tersedia pecel lele & Sedia pecel lel \\
\hline 7. & Dikontrak rumah & Dikontrakkan rumah \\
\hline 8. & terpercaya & tepercaya \\
\hline 9. & sabuk keselamatan & sabuk pengaman \\
\hline 10. & Unit Pelaksana & Unit \\
& Tehnis & Teknis \\
\hline 11. & tanggungjawab & tanggung jawab \\
\hline 12. & Terimakasih & Terima kasih \\
\hline
\end{tabular}

\subsubsection{Kalimat}

Permasalahan dalam hal kalimat umumnya terletak pada struktur kalimat yang kurang benar, 
misalnya dalam kalimat yang di dalamnya terdapat perincian. Seringkali sebelum perincian diberi tanda titik dua untuk memulai perincian, tetapi anehnya kata berikutnya diawali dengan huruf kapital yang menandakan bahwa kata itu sebagai awal kalimat. Selain itu pada akhir kalimat tidak diberi tanda titik yang menandai bahwa kalimat tersebut selesai. Contoh:

\begin{tabular}{|c|c|c|}
\hline NO. & SALAH & BENAR \\
\hline 1. & $\begin{array}{l}\text { Pastikan tanah Anda: } \\
\text { - Mempunyai Tanda Batas } \\
\text { - Bersertifikat } \\
\text { - } \quad \text { Tidak Ditelantarkan } \\
\text { Agar terhindar dari sengketa tanah }\end{array}$ & $\begin{array}{l}\text { Pastikan tanah Anda: } \\
\text { - mempunyai tanda batas, } \\
\text { - bersertifikat, dan } \\
\text { - tidak ditelantarkan } \\
\text { agar terhindar dari sengketa tanah. }\end{array}$ \\
\hline 2. & $\begin{array}{l}\text { RUMAH BERSALIN DR. Idil Fitri, SpoG } \\
\text { Melayani: } \\
\begin{aligned}- & \text { Persalinan, periksa hamil } \\
- & \text { Imunisasi, keluaraga berencana } \\
\text { - } & \text { Kesehatan ibu dan anak dll }\end{aligned}\end{array}$ & $\begin{array}{l}\text { Rumah Bersalin dr. Idil Fitri, Sp.O.G. } \\
\text { melayani: } \\
\begin{array}{l}\text { - } \\
\text { - }\end{array} \text { imunisasi dan keluaraga berencana; dan } \\
\text { - } \quad \text { pelayanan kesehatan ibu dan anak; } \\
\text { - } \quad \text { dan lain-lain. }\end{array}$ \\
\hline 3. & $\begin{array}{l}\text { Datanglah...buktikan dan } \\
\text { keramaahtamahan kami dan semua tujuan } \\
\text { wisata ditanah kami yang tercinta bagi } \\
\text { kenangan anda }\end{array}$ & $\begin{array}{l}\text { Datanglah, buktikan, dan nikmati keramaahtamahan } \\
\text { dan semua tempat wisata di tanah kami tercinta untuk } \\
\text { kenangan Anda. }\end{array}$ \\
\hline 4. & $\begin{array}{l}\text { NARKOBA MENGANCAM SETIAP SAAT } \\
\text { SETIAP TEMPAT } \\
\text { JAGA DIRIMU DAN KELUARGAMU }\end{array}$ & $\begin{array}{l}\text { NARKOBA MENGANCAM PADA SETIAP SAAT } \\
\text { DAN DI SETIAP TEMPAT. } \\
\text { JAGA DIRIMU DAN KELUARGAMU. }\end{array}$ \\
\hline 5. & $\begin{array}{l}\text { DIUSIA } 11 \text { TAHUN PROVINSI } \\
\text { KEPULAUAN BANGKA BELITUNG KITA } \\
\text { TINGKATKAN KEBERSAMAAN } \\
\text { KEPEDULIAN SERTA TANGGUNG } \\
\text { JAWAB MEWUJUDKAN NEGERI } \\
\text { SERUMPUN SEBALAI YANG LEBIH } \\
\text { SEJAHTERA DAN BERDAYA SAING } \\
\text { GLOBAL }\end{array}$ & $\begin{array}{l}\text { PADA USIA KE-11 TAHUN PROVINSI } \\
\text { KEPULAUAN BANGKA BELITUNG KITA } \\
\text { TINGKATKAN KEBERSAMAAN, KEPEDULIAN, } \\
\text { DAN TANGGUNG JAWAB UNTUK } \\
\text { MEWUJUDKAN NEGERI SERUMPUN SEBALAI } \\
\text { YANG LEBIH SEJAHTERA DAN BERDAYA } \\
\text { SAING GLOBAL. }\end{array}$ \\
\hline
\end{tabular}

\subsubsection{Pengaruh Bahasa Asing atau Bahasa Daerah}

Permasalahan yang paling umum dan banyak terjadi pada bahasa informasi di rung publik di Kota Pangkalpinang adalah adanya penggunaan bahasa asing, utamanya bahasa Inggris, yang berlebihan. Bahkan, untuk kategori komunikator sektor swasta penggunaan bahasa asing sangat mendominasi hampir di seluruh bahasa informasi di ruang publik. Hal itu tidak hanya terjadi pada bahasa informasi dari perusahaan-perusahaan dan took-toko besar, tetapi toko-toko kecil pun ramai-ramai menggunakan bahasa Inggris yang bercampur dengan bahasa Indonesia. Padahal, sasaran iklan atau informasi umumnya adalah masyarakat lokal (Indonesia) dan sangat jarang orang asing. Selain itu pada beberapa tempat juga terdapat penggunaan bahasa informasi dengan menggunakan bahasa daerah meskipun jumlahnya tidak terlalu banyak. Berikut ini contoh pemakaian bahasa informasi yang terpengaruh bahasa asing dan daerah. 
Umar Solikhan: Bahasa Indonesia dalam Informasi dan Iklan di Ruang...

\begin{tabular}{|l|l|l|}
\hline NO. & \multicolumn{1}{|c|}{ SALAH } & \multicolumn{1}{c|}{ BENAR } \\
\hline 1. & WELCOME TO PANGKALPINANG & SELAMAT DATANG DI PANGKALPINANG \\
\hline 2. & $\begin{array}{l}\text { Consumer Service Area Bangka Belitung } \\
\text { Plasa Telkom Pangkalpiang }\end{array}$ & $\begin{array}{l}\text { Pelayanan Konsumen Wilayah Bangka Belitung } \\
\text { Plaza Telkom Pangkalpiang }\end{array}$ \\
\hline 3. & $\begin{array}{l}\text { Rapih Gordyn } \\
\text { Interior Decoration }\end{array}$ & $\begin{array}{l}\text { Gordin Rapih } \\
\text { Dekorasi Interior }\end{array}$ \\
\hline 4. & $\begin{array}{l}\text { Lenny Bakery \& Cake } \\
\text { A little bliss in Every Bite }\end{array}$ & $\begin{array}{l}\text { Toko Roti dan Kue Lenny } \\
\text { Sedikit Kebahagiaan dalam Setiap Gigitan }\end{array}$ \\
\hline 5. & Ramfi baby \& Kids Shop & $\begin{array}{l}\text { Ramfi } \\
\text { Toko Perlengkapan Bayi dan Anak-Anak }\end{array}$ \\
\hline 6. & $\begin{array}{l}\text { Al Jalil Laundry \& Dry Cleaning } \\
\text { Menerima Pencucian: Laundry Higienis Harga } \\
\text { Ekonomis }\end{array}$ & $\begin{array}{l}\text { Binatu dan Cuci Kering Al Jalil } \\
\text { Melayani jasa cuci bersih, harga ekonomis }\end{array}$ \\
\hline 7. & $\begin{array}{l}\text { Yo...KITE MEMBAYAR PAJAK UNTUK } \\
\text { MEMBANGUN DAERAH KITE }\end{array}$ & $\begin{array}{l}\text { MARI KITA MEMBAYAR PAJAK UNTUK } \\
\text { MEMBANGUN DAERAH KITA }\end{array}$ \\
\hline
\end{tabular}

\subsection{Pemakaian Bahasa sebagai Wujud Sikap Bahasa Masyarakat}

Seperti diketahui bahwa kesalahan pemakaian bahasa Indonesia di tempat umum dilakukan oleh berbagai kalangan. Namun, jika lebih dispesifikkan penilaiannya, kalangan dunia usaha swasta merupakan pihak yang cukup banyak melakukan kesalahan dibanding kalangan dari unsur pemerintah. Hal itu dapat dimaklumi mengingat kalangan swasta lebih beragam karena berasal dari berbagai latar belakang. Lain halnya dengan unsur pemerintah, misalnya instansi-instansi yang ada di pemerintah daerah, latar belakangnya cenderung lebih seragam. Bahkan untuk tulisan atau informasi mengenai hal tertentu mungkin sudah ada kebijakan tertentu dari pemda sehingga informasi yang dikeluarkan intansi-instansi yang ada di bawah pemda cenderung seragam.

Dari analisis diketahui bahwa kesalahan ejaan merupakan kesalahan yang banyak terjadi dalam penulisan informasi di tempat umum. Sebenarnya kita merasa prihatin terhadap masalah itu mengingat pedoman ejaan bahasa Indonesia yang disempurnakan (EYD) sudah sangat lama diberlakukan. Namun demikian, kesalahan-kesalahan dalam penulisan ejaan masih sering terjadi. Penyebabnya bermacam-macam, antara lain ketidaktahuan mereka terhadap aturanaturan yang ada dalam ejaan. Sebenarnya jika dikatakan tidak tahu kurang tepat juga mengingat mereka yang pernah sekolah di SD sampai SMA pasti pernah mempelajari masalah ejaan dalam pelajaran bahasa Indonesia. Jadi, sebenarnya mereka sudah mengetahui hanya saja lupa terhadap ketentuanketentuan yang ada dalam EYD karena mungkin memang sudah lama tidak mempelajarinya. Penyebab utamanya adalah keengganan mereka untuk melihat buku pedoman EYD apalagi bagi orang yang dalam kehidupan sehari-hari dan dalam pekerjaannya tidak bersentuhan dengan masalah bahasa. Di samping itu, faktor menyepelekan juga dapat menjadi penyebab mengapa banyak penulis melakukan kesalahan. Hal itu memang tidak bisa dipungkiri dari kenyataan yang ada pada masyarakat sekarang. Orang-orang menganggap berkomunikasi dengan bahasa Indonesia sangat mudah karena hampir semua orang terutama di kota sudah mengerti bahasa Indonesia. Akibatnya mereka yang akan memberi informasi tidak begitu memedulikan kaidah yang berlaku karena menganggap masyarakat mengerti apa yang disampaikan oleh pemberi informasi. Jadi, dapat dikatakan mereka "menggampangkan" bentuk bahasa atau lebih mementingkan isi pesan daripada bentuk. Padahal, bentuk bahasa juga merupakan hal yang penting karena dari bentuk itulah keefektifan isi/makna informasi dapat diungkapkan.

Situasi tersebut didukung oleh iklim globalisasi yang mendorong orang ingin dapat menguasai bahasa asing, terutama bahasa Inggris. Orang-orang beranggapan bahasa Inggris mempunyai prestise lebih tinggi daripada bahasa Indonesia sehingga orang berlomba mempelajari bahasa Inggris. 
Berdasarkan pemantauan, situasi yang memprihatinkan tersebut tampaknya lebih banyak terjadi di masyarakat perkotaan. Orang-orang yang lebih maju dari segi pendidikan dan luas dari segi pergaulan tampaknya cenderung lebih menyepelekan bahasa Indonesia. Berbeda dengan masyarakat di perdesaan yang lebih menghargai bahasa Indonesia. Sikap mereka lebih positif karena masih menganggap bahasa Indonesia bernilai tinggi. Pengalaman penulis ketika mengadakan penelitian kebahasaan di pedalaman Papua pada tahun 2007 melihat betapa masyarakat di daerah Papua, khususnya di pedalaman, menganggap bahasa Indonesia sangat penting peranannya sebagai alat komunikasi, terutama antarsuku. Dari situ tampaknya terdapat korelasi antara sikap orang/masyarakat terhadap bahasa dan pemakaian bahasa mereka. Dengan demikian, masalah sikap terhadap bahasa merupakan faktor yang menentukan bagaimana mereka menggunakan bahasa tersebut. Jika sikap mereka terhadap bahasa Indonesia positif, penggunaan bahasa Indonesia mereka akan baik dan sebaliknya jika sikap mereka kurang positif, penggunaan bahasa Indonesia mereka akan kurang baik pula.

\section{PENUTUP}

Pemakaian bahasa Indonesia, khususnya dalam informasi dan iklan, di tempat umum di wilayah Pangkalpinang belum menggambarkan pemakaian bahasa Indonesia yang baik dan benar. Hal itu disebabkan antara lain oleh sikap terhadap bahasa Indonesia yang masih belum memenuhi harapan. Padahal, sebagai bangsa yang berbudaya dan menjunjung persatuan bangsa Indonesia, sikap positif terhadap bahasa Indonesia senantiasa harus dijaga. Dengan demikian, bahasa Indonesia akan selalu terpelihara dan dapat menjalankan fungsinya sebagai bahasa persatuan.

\section{DAFTAR PUSTAKA}

Alwi, Hasan; Soenjono Dardjowidjojo; Hans Lapoliwa; Anton M. Moeliono. 2003. Tata Bahasa Baku Bahasa Indonesia. Jakarta: Balai Pustaka

Departemen Pendidikan Nasional. 2004. Pedoman Umum Ejaan Bahasa Indonesia Yang Disempurnakan. Jakarta: Pusat Bahasa.

2008. Kamus Besar Bahasa Indonesia. Edisi Keempat. Jakarta: PT Gramedia Pustaka Utama.

Badan Pengembangan dan Pembinaan Bahasa, Kementerian Pendidikan Nasional. 2011. Undang-Undang Republik Indonesia Nomor 24 Tahun 2009 tentang Bendera, Bahasa, dan Lambang Negera, serta Lagu Kebangsaan.

Halim, Amran. 1978. "Sikap Bahasa dan Pelaksanaan kebijaksanaan Bahasa Nasional. "Dalam Amran Halim dan Yayah B. Lumintaintang. Editor. Kongres Bahasa Indonesia III. Jakarta: Pusat Pembinaan dan Pengembangan Bahasa.

Mahsun. 2005. Metode Penelitian Bahasa Tahapan Starategi, Metode, dan Tekniknya. Jakarta: PT Raja Grafindo Persada.

Shurter, Robert L. 1971. Written Communication in Bussiness. $3^{\text {rd }}$ ed. New York: Mc. Graw-Hill.

Sugono, Dendy (ed). 2011. Buku Praktis Bahasa Indonesia 1. Jakarta: Badan Pengembangan dan Pembinaan Bahasa

2011. Buku Praktis Bahasa Indonesia 2. Jakarta: Badan Pengembangan dan Pembinaan Bahasa

Suhardi, Basuki. 1996. "Sikap Bahasa: Suatu Telaah Eksploratif atas Sekelompok Sarjana dan Mahasiswa di Jakarta". Depok: Fakultas Sastra, Universitas Indonesia. 